\title{
Ectonucleoside Triphosphate Diphosphohydrolase 1
}

National Cancer Institute

\section{Source}

National Cancer Institute. Ectonucleoside Triphosphate Diphosphohydrolase 1. NCI

Thesaurus. Code C113581.

Ectonucleoside triphosphate diphosphohydrolase 1 ( $510 \mathrm{aa}, \sim 58 \mathrm{kDa}$ ) is encoded by the human ENTPD1 gene. This protein is involved in the activation of platelets. 